\title{
Relaxant Effect of Urginea maritima on Tracheal Smooth Muscle Mediated by the Effect on Beta-2 Adrenergic, Muscarinic Receptors and Calcium and Potassium Channels
}

\author{
Hamideh Kazemi Rad, ${ }^{1}$ Arghavan Memarzia, ${ }^{2}$ Fatemeh Amin $\mathbb{D}^{3,4}$ \\ and Mohammad Hossein Boskabady $\mathbb{D}^{1,2}$ \\ ${ }^{1}$ Applied Biomedical Research Center, Mashhad University of Medical Sciences, Mashhad, Iran \\ ${ }^{2}$ Department of Physiology, Faculty of Medicine, Mashhad University of Medical Sciences, Mashhad, Iran \\ ${ }^{3}$ Non-Communicable Diseases Research Center, Rafsanjan University of Medical Sciences, Rafsanjan, Iran \\ ${ }^{4}$ Department of Physiology and Pharmacology, School of Medicine, Rafsanjan University of Medical Sciences, Rafsanjan, Iran
}

Correspondence should be addressed to Mohammad Hossein Boskabady; boskabadymh@mums.ac.ir

Received 31 December 2020; Revised 27 March 2021; Accepted 6 April 2021; Published 21 April 2021

Academic Editor: Gabriel A. Agbor

Copyright $\odot 2021$ Hamideh Kazemi Rad et al. This is an open access article distributed under the Creative Commons Attribution License, which permits unrestricted use, distribution, and reproduction in any medium, provided the original work is properly cited.

\begin{abstract}
Urginea maritima (U. maritima) showed anti-inflammatory, antioxidant, antibacterial, diuretic, vasodilatation, and woundhealing effects on fungal infections, cardiac disorders, digestive disorders, rheumatoid disease, and respiratory disorders such as bronchitis, bronchial nosocomial infections, and severe cough. To examine the bronchodilatory effect of U. maritima, the relaxant effect of its extract on rat tracheal smooth muscle (TSM) and its possible mechanism was examined in this study. Male Wistar rats' TSM were divided into eight groups ( $n=8$ in each group). Four of these groups were TSM tissues, contracted with $\mathrm{KCl}(60 \mathrm{mM})$ incubated with atropine, glibenclamide, and indomethacin and nonincubated TSM, while the other four groups were TSM tissues contracted with methacholine $(10 \mu \mathrm{M})$ for $5 \mathrm{~min}$, incubated with propranolol, chlorpheniramine, and diltiazem and nonincubated TSM. Cumulative concentrations of $U$. maritima extract $(12.5,25,50,100,20$, and $400 \mu \mathrm{g} / \mathrm{ml}) \mathrm{were}$ then added to organ bath every $5 \mathrm{~min}$. Theophylline $(0.2,0.4,0.6$, and $0.8 \mathrm{mM})$ as positive control and saline $(1 \mathrm{ml})$ as negative control were also examined in nonincubated tissues. A concentration-dependent relaxant effect of $U$. maritima on nonincubated TSM contracted with $\mathrm{KCl}(60 \mathrm{mM})$ or methacholine $(10 \mu \mathrm{M})(p<0.01$ and $p<0.001)$ was observed. The relaxant effects of $U$. maritima extract in the incubated tissues with glibenclamide, propranolol, diltiazem, atropine, and chlorpheniramine were significantly lower than those in the nonincubated tissues $(p<0.05$ to $p<0.001)$. $\mathrm{EC}_{50}$ values of $U$. maritima extract in the incubated TSM with glibenclamide, propranolol, diltiazem, and atropine were significantly higher than those in the nonincubated tissues ( $p<0.05$ for diltiazem-incubated tissues and $p<0.001$ for other cases). U. maritima extract displayed considerable relaxant effect on TSM comparable to the effect of theophylline. Beta-2 adrenoceptor stimulation and muscarinic receptor inhibition as well as potassium opening and calcium channels blocking effects are the possible mechanisms for the relaxant effects of the plant.
\end{abstract}

\section{Introduction}

One of the most important chronic inflammatory diseases in the world is asthma with considerable morbidity. Asthma is characterized by pathological changes in the lung, like increased mucosa secretion, airway hyperresponsiveness, infiltration of inflammatory cells, and smooth muscle hyperplasia [1]. Over the past 30 years, there has been an increase in the number of patients with asthma, and 250,000 people die from this disease each year. The treatment of this disease is very costly and the direct and indirect costs of the asthma are globally on the rise [2]. The precise mechanism of asthma pathophysiology and the role of biochemical intermediates involved in asthma are not yet known, but, 
based on available information, leukotrienes, prostaglandins, histamine, nitric oxide, and type II immune response cytokines are among the most important mechanisms involved in the pathophysiology of asthma. These mechanisms cause airway inflammation as well as bronchospasm in asthmatic patients [3]. The adrenoceptor and cholinergic pathways affected the airway smooth muscle tone. Cholinergic control is performed by the vagal reflex and through stimulatory receptors located below the mucous membranes of the large respiratory tract and upper respiratory tract. The stimulation of these receptors by inhaled stimulants or inflammation causes obstruction of large airways. Androgen intermediates like histamine and prostaglandins may cause bronchial smooth muscle contraction directly or reflexively through stimulation of receptors [4].

The tendency to use treatments with minimizing side effects such as the use of medicinal herbs which may cause a decrease in drug resistance has increased in recent years [5]. Urginea maritime (U. maritima) is a flowering plant of the Asparagaceae family and the Scilloideae subfamily, known as squill, sea squill, and onion, growing in the Mediterranean, North Africa, and India [6, 7]. U. maritima contains a large number of glycosides, type bufadienolide, where scillaren A is an important component of all glycosides. U. maritima also contains an aclicon called scillaridin $\mathrm{A}$ and small amounts of other cardiac glycosides, such as glucoscillaren A, proscillaridin A [8], other flavonoids, fatty acids, anthocyanins, and related carbohydrates $[9,10]$. U. maritima plant has been widely used in cardiac disorders and fungal infections and as a diuretic agent, and the fresh U. maritima extract is more active than the dried fruits [11]. Constituents of methanolic extract of $U$. maritima exhibited antioxidant and antibacterial activity [12]. A previous document exhibited biological activity of Urginea species [13]. The plant also displayed antibacterial activity, inhibition of the growth of an ascites tumor [14], and cardiotonic and diuretic effects [15]. The potent digitalis-like cardiac effect of the plant was described for centuries [16], and it showed heart stimulatory and diuretic effects [17]. Fresh bulbs of this species are used to accelerate wound-healing, as well as in digestive disorders and rheumatoid disease [18]. The effect of this plant on the treatment of cancer was also shown [19]. It showed cytotoxicity against human breast carcinoma cells (MCF-7) in vitro [20]. U. maritima extract also caused peripheral vasodilatation in anesthetized rabbits [21] and it showed similar effect to that of digitalis on the heart. $U$. maritima is traditionally used to treat bronchitis, bronchial nosocomial infections, severe cough, and edema [22, 23].

Therefore, to examine the bronchodilatory effect of $U$. maritima, this study sought to investigate the relaxant effect mechanisms of action of its extract on tracheal smooth muscle (TSM) in Wistar rats.

\section{Materials and Methods}

2.1. Preparation of the Extract. U. maritima was purchased from a market in Mashhad, Iran, in October 2018 and identified by Dr. Rakhshandeh, Pharmacological Research Center of Medicinal Plants and Department of
Pharmacology, Faculty of Medicine, Mashhad University of Medical Sciences, Mashhad, Iran. U. maritima extract was prepared by peeling, weighed $(50 \mathrm{~g})$, and soaked in $70 \%$ ethanol (ethanol $96^{\circ}$, Taghtir Khorasan Co., Iran) at $40^{\circ} \mathrm{C}$ for 72 hours while shaking constantly. The extract was dried by rotary evaporator at $50^{\circ} \mathrm{C}$ to obtain a yield of $12 \%$ and the required concentrations were prepared.

2.2. Animals and Experimental Groups. Sixty-four male Wistar rats (weight, 200-250) were kept in a standard condition, $22 \pm 2^{\circ} \mathrm{C}$ temperature, $12 \mathrm{~h} \mathrm{light} / \mathrm{dark}$ cycles, and free access to standard diet and tap water in the Animal House, School of Medicine, Mashhad University of Medical Sciences, Mashhad, Iran. The study was approved by the Ethics Committee of Mashhad University of Medical Sciences (\#961800). All experiments on animals were done according to National Laws regarding the use and care of laboratory animals. Animals were divided into eight groups ( $n=8$ in each group) as shown in Table 1.

2.3. Tissue Preparation. The rats were sacrificed after anesthetizing by $1.6 \mathrm{~g} / \mathrm{kg}$ intraperitoneal (i.p.) administration of urethane and their chests opened. Tracheal rings of rats containing three cartilages were prepared from the middle section of trachea as previously described [24] and mounted in a $10 \mathrm{ml}$ organ bath containing Krebs-Henseleit solution supplied with $95 \% \mathrm{O}_{2}$ and $5 \% \mathrm{CO}_{2}$ and tissue responses were measured using an isometric transducer (MLT0202, AD Instruments, Australia) connected to a power lab system (Power Lab 8/30, ML870, AD Instruments, Australia) exactly as previously described [24-26].

\subsection{Examination of Smooth Muscle Relaxant Effect of Plant} Extract. TSM was contracted by $\mathrm{KCl}(60 \mathrm{mM})$ (Merck Chemical Ltd., Germany) or methacholine $(10 \mu \mathrm{M})$ (Sigma Chemical Ltd., UK) [26]. It was well established that $\mathrm{KCl}$ contracts tracheal smooth muscles by depolarizing the smooth muscle cells and methacholine contracts them by muscarinic receptor stimulation [24, 26]. After 5 minutes, cumulative concentrations of extract of $U$. maritima (12.5, $25,50,100,20$, and $400 \mu \mathrm{g} / \mathrm{ml})$ [27] and theophylline $(0.2$, $0.4,0.6$, and $0.8 \mathrm{mM})$ as positive control or saline $(1 \mathrm{ml})$ as negative control were added to organ bath every 5 minutes $[25,26]$.

The reduction of contraction produced contractile agents ( $\mathrm{KCl}$ or methacholine) due to the fact that each concentration of $U$. maritima extract and theophylline in proportion to maximum contractile response was calculated and considered as percent relaxation response [24]. The relaxation concentration response curves were prepared, and the extract concentration causing 50\% of maximum relaxation effect $\left(\mathrm{EC}_{50}\right)$ was measured from concentration response curve as previously defined [24-26, 28-31]. In incubated tissues with rightward shift in the concentration-response curve of the relaxant effect of the plant, the concentration ratio minus one (CR-1) was 
TABLE 1: Experiment groups. Trachea of incubated groups subjected to different channel blocker or antagonists in organ bath first followed by contraction of TSM by $\mathrm{KCl}$ or methacholine after $10 \mathrm{~min}$.

\begin{tabular}{|c|c|c|c|c|}
\hline Contractile agent & Condition & Incubating agent & Mechanisms & $n$ \\
\hline \multirow{4}{*}{$\mathrm{KCl}(60 \mathrm{mM})$} & Nonincubated tissues & - & - & $n=8$ \\
\hline & \multirow{3}{*}{ Incubated tissues } & Atropine $(1 \mu \mathrm{M})$ & Muscarinic receptor inhibition & $n=8$ \\
\hline & & Indomethacin $(1 \mu \mathrm{M})$ & Cyclooxygenase inhibition & $n=8$ \\
\hline & & Chlorphenamine $(1 \mu \mathrm{M})$ & Histamine (H1) receptor inhibition & $n=8$ \\
\hline \multirow{4}{*}{ Methacholine $(10 \mu \mathrm{M})$} & Nonincubated tissues & - & - & $n=8$ \\
\hline & \multirow{3}{*}{ Incubated tissues } & Diltiazem $(5 \mu \mathrm{M})$ & Calcium channel blocking & $n=8$ \\
\hline & & Glibenclamide $(1 \mu \mathrm{M})$ & Potassium channel opening & $n=8$ \\
\hline & & Propranolol $(1 \mu \mathrm{M})$ & $\mathrm{B}_{2}$-adrenoceptor stimulation & $n=8$ \\
\hline
\end{tabular}

also estimated as $\left(\mathrm{EC}_{50}\right.$ in the incubated tissues/EC $\mathrm{E}_{50}$ in nonincubated tissues) -1 .

In two groups, the relaxant effect of $U$. maritima extract was examined on $\mathrm{KCl}$ - or methacholine-contracted on nonincubated TSM to evaluate the possible relaxant effect of the plant and its possible effect on potassium channels and muscarinic receptors, respectively. In addition, in six groups, the relaxant effects of the extract on incubated TSM tissues with atropine, glibenclamide, and indomethacin, contracted by $\mathrm{KCl}$, as well as incubated TSM with propranolol, chlorpheniramine, and diltiazem, contracted by methacholine, were examined to evaluate different possible mechanisms responsible for the relaxant effect of $U$. maritima extract as described in Table 1 . The duration of the examination of the relaxant effect of the extract including mounting the tracheal ring in the organ bath, tissue equilibration, TSM contraction, and evaluation of the relaxant effect in each experiment was about 100 minutes.

2.5. Statistical Analysis. Statistical comparisons were performed using InStat software. The data was presented as mean \pm standard error of the mean (SEM). Comparisons were performed using ANOVA followed by Tukey's multiple comparisons test and $p<0.05$ was considered as a significant criterion.

\section{Results}

3.1. The Relaxant Effect of U. maritima Extract on TSM Contraction Induced by Methacholine in Nonincubated and Incubated Tissues. Concentration-dependent and significant relaxant effects of the extract of $U$. maritima and theophylline were seen on TSM contracted by methacholine ( $p<0.05$ for the second extract concentration and $p<0.001$ for all theophylline and higher extract concentrations).

The relaxant effects of two higher concentrations of $U$. maritima extract ( 200 and $400 \mu \mathrm{g} / \mathrm{ml}$ ) were significantly less than the relaxant effects of the two higher concentrations of theophylline ( $p<0.05$ for both cases) (Figure 1(a)).

Different concentrations of $U$. maritima extract showed significant relaxant effects on TSM in incubated tissue with glibenclamide $(p<0.001$ for 5 last concentrations). However, in incubated tissues with glibenclamide, the relaxant effects of 100 and $200 \mu \mathrm{g} / \mathrm{ml}$ concentrations of the extract were significantly lower than those in the nonincubated
TSM $(p<0.001$ and 0.05 for 100 and $200 \mu \mathrm{g} / \mathrm{ml}$ concentrations, respectively) (Figure $1(\mathrm{~b})$ ). $\mathrm{EC}_{50}$ values of the $U$. maritima extract for its relaxant effect in incubated TSM with glibenclamide were significantly higher than those in nonincubated tissues (Figure 2(a)).

A rightward shift in the concentration-response relaxation curve of the $U$. maritima extract was observed; in glibenclamide-incubated TSM compared to nonincubated tissues, a maximum response was achieved. The (CR-1) value of the extract in incubated TSM with glibenclamide was $0.6 \pm 0.2$.

The relaxant effects of different concentrations of $U$. maritima extract on incubated tissue with propranolol were significantly higher than the effect of saline $(p<0.01$ for the second and $p<0.001$ for higher extract concentrations). The relaxant effects of four higher concentrations of the extract in incubated TSM with propranolol were significantly lower than those in the nonincubated tissues $\left(p<0.001\right.$ for all cases, (Figure 3(a)). EC $\mathrm{E}_{50}$ value of the $U$. maritima extract for its relaxant effect in incubated tissues with propranolol was significantly higher than that in the nonincubated TSM $(p<0.001)$ (Figure 2(a)). A rightward shift in concentration-response relaxation curve of the $U$. maritima extract was observed in propranolol-incubated TSM compared to nonincubated tissues but the maximum response was not achieved. The (CR-1) value of the extract in incubated TSM with propranolol was $2.3 \pm 0.4$.

Different concentrations of $U$. maritima extract caused significant relaxant effects in incubated tissues with diltiazem compared to the effect of saline $(p<0.001$ for 5 last concentrations). The relaxant effects of 50 and $100 \mu \mathrm{g} / \mathrm{ml}$ of the extract in incubated tissue with diltiazem were significantly lower than those in the nonincubated TSM $(p<0.05$ for both cases) (Figure 3(b)).

$\mathrm{EC}_{50}$ values of the $U$. maritima extract for its relaxant effect in incubated TSM with diltiazem were significantly higher than those in the nonincubated tissues $(p<0.05)$ (Figure 2(a)). A rightward shift in concentration-response relaxation curve of the extract was observed in diltiazemincubated TSM compared to nonincubated tissues and the maximum response was achieved. The (CR-1) value of the extract in incubated TSM with diltiazem was $0.43 \pm 0.1$.

3.2. The Relaxant Effect of U. maritima Extract on TSM Contraction Induced by KCl in Nonincubated and Incubated 

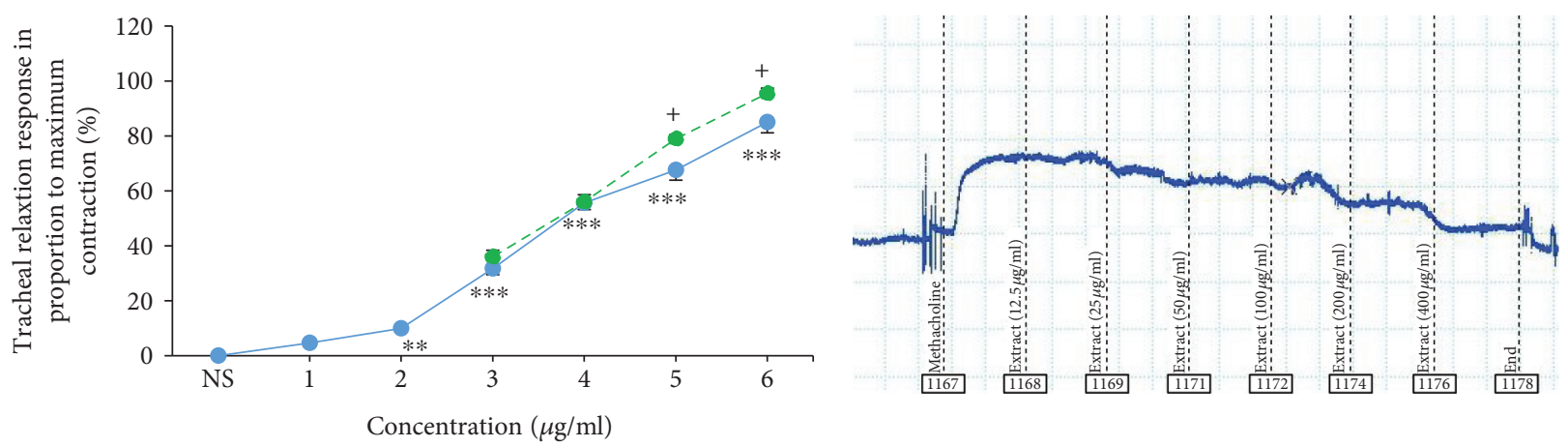

$\rightarrow$ U-matima extract

- Theophylline

(a)
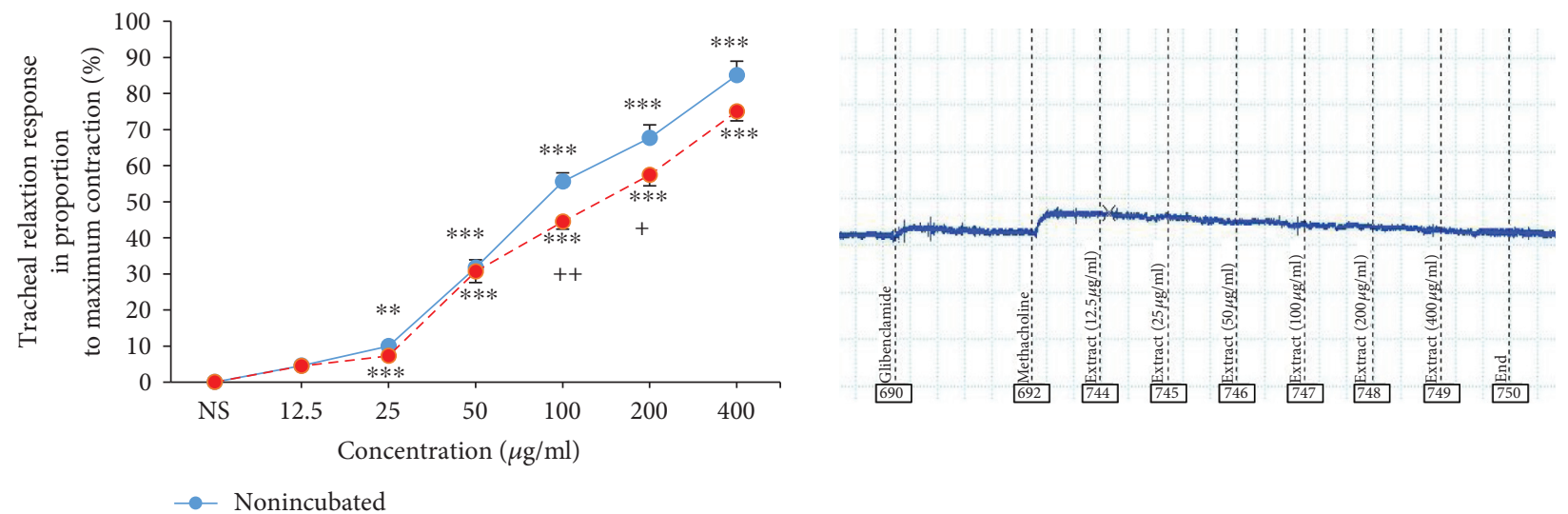

(b)

FIGURE 1: Concentration-response relaxant effects (mean \pm SEM) of theophylline and U. maritima extract in nonincubated TSM contracted by $10 \mu \mathrm{M}$ methacholine $(n=7) .1,2,3,4,5$, and 6 in $X$-axis display six concentrations of the extract $(12.5,25,50,100,20$, and $400 \mu \mathrm{g} / \mathrm{ml})$ and $3,4,5$, and 6 display theophylline concentrations $(0.2,0.4,0.6$, and $0.8 \mathrm{mM})$ and (b) concentration-response relaxant effects (mean \pm SEM) of theophylline and U. maritima extract in glibenclamide-incubated TSM $(1 \mu \mathrm{M}, n=8)$. ${ }^{* *} p<0.01$ and ${ }^{* * *} p<0.001$ compared to the effect of saline (NS), ${ }^{+} p<0.05$ in panel (a) indicates comparison between the effect of theophylline and that of the extract. ${ }^{+} p<0.05$ and ${ }^{++} p<0.01$ in panel (b) show the comparison of the effect of the extract between incubated and nonincubated tissues. ANOVA with the Tukey-Kramer post hoc test was used for statistical comparison.

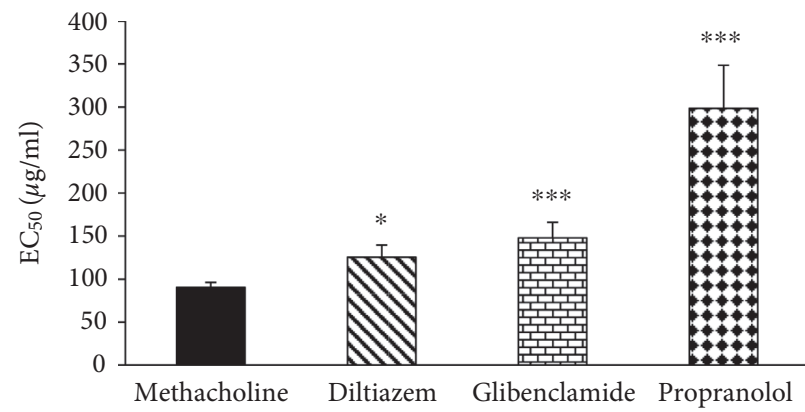

(a)

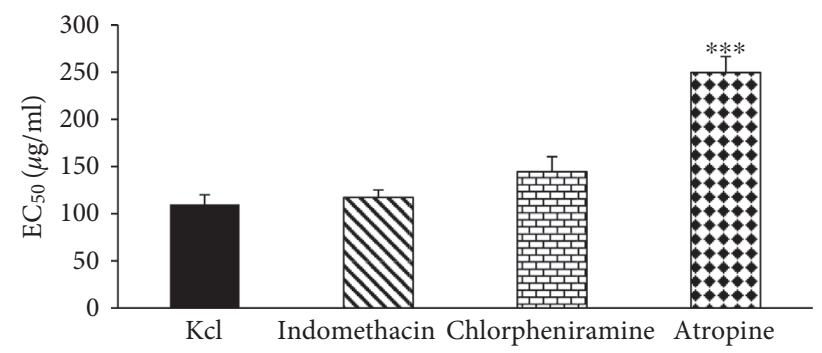

(b)

FIgURE 2: $\mathrm{EC}_{50}$ values of $U$. maritima extract-induced TSM relaxation in nonincubated and incubated TSM with various agents and contracted with methacholine (a) or $\mathrm{KCl}$ (b). ${ }^{*} p<0.05$ and ${ }^{* * *} p<0.001$ compared to nonincubated tissues. ANOVA with the Tukey-Kramer post hoc test was used for statistical comparison. 


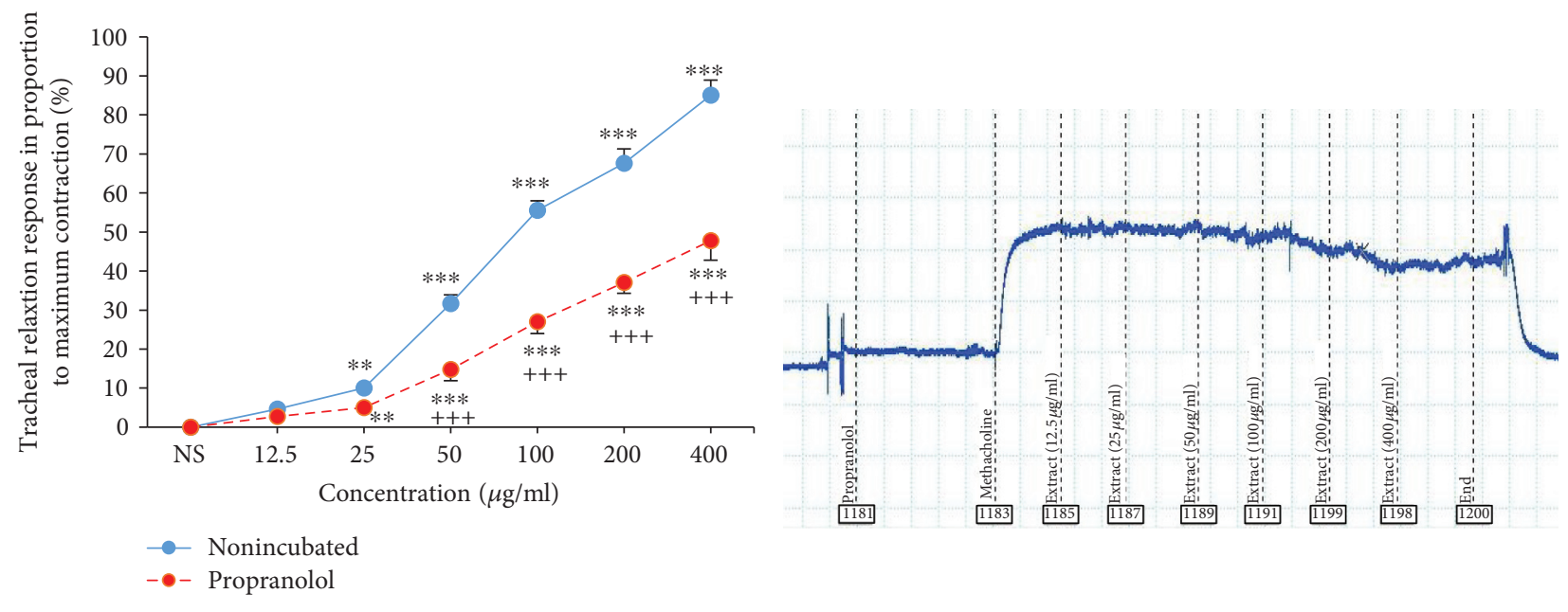

(a)

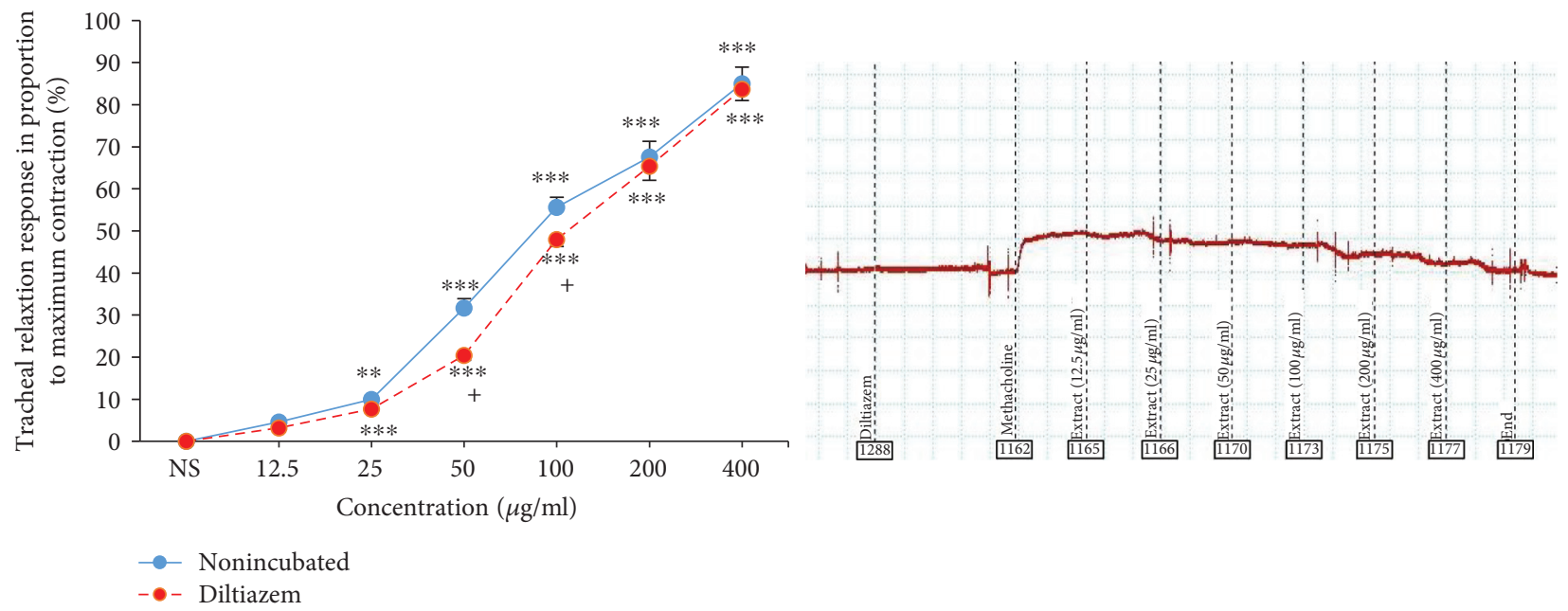

(b)

Figure 3: Concentration-response relaxant effects (mean \pm SEM) of the U. maritima extract on $10 \mu \mathrm{M}$ methacholine-induced contraction of TSM in nonincubated and propranolol-incubated $(1 \mu \mathrm{M})(\mathrm{a})$ and diltiazem-incubated TSM $(1 \mu \mathrm{M})(\mathrm{b})\left(n=8\right.$ for all groups). ${ }^{* * *} p<0.001$, compared to the effect of saline (NS), ${ }^{+} p<0.05$, compared to the effect of the extract on nonincubated tissues. ANOVA with the Tukey-Kramer post hoc test was used for statistical comparison.

Tissues. In nonincubated TSM contracted by $\mathrm{KCl}$, the relaxant effects of all concentrations of $U$. maritima extract and theophylline were higher than the effect of saline $(p<0.001$ for all cases except the low extract concentration). The relaxant effects of $0.2,0.6$, and $0.8 \mathrm{mM}$ theophylline were significantly higher than those of the corresponding concentrations of the extract $(p<0.05$ to $p<0.001)$ (Figure $4(\mathrm{a})$ ).

The extract of $U$. maritima showed significant and concentration-dependent relaxant effects on incubated TSM with atropine ( $p<0.05$ for $25 \mu \mathrm{g} / \mathrm{ml}$ and $p<0.001$ for higher extract concentrations). The relaxant effects of four higher concentrations of the extract in incubated tissue with atropine were significantly lower compared to those in the nonincubated TSM ( $p<0.001$ for all cases) (Figure 4(b)).

$E_{50}$ values of the extract for its relaxant effect in incubated TSM with atropine were significantly higher compared to those in the nonincubated tissues with atropine $(p<0.001)$ (Figure 2(b)).
A rightward shift in concentration-response curve of the extract was seen in atropine-incubated TSM compared to nonincubated tissues and the maximum response was achieved. The (CR-1) value of the extract in incubated TSM with atropine was $1.6 \pm 0.2$.

The relaxant effects in 5 higher concentrations of extract in incubated TSM with chlorpheniramine and indomethacin were significantly higher compared to the effect of saline $(p<0.05$ for $25 \mu \mathrm{g} / \mathrm{ml}$ in chlorpheniramine-incubated tissues and $p<0.001$ for higher extract concentrations). There was no significant difference between the effects of different concentrations of extract in incubated TSM with chlorpheniramine and indomethacin and nonincubated tissues (Figures 5(a) and 5(b)).

3.3. Comparison of the Relaxant Effect of U. maritima Extract between TSM Contracted by Methacholine and $\mathrm{KCl}$. There 

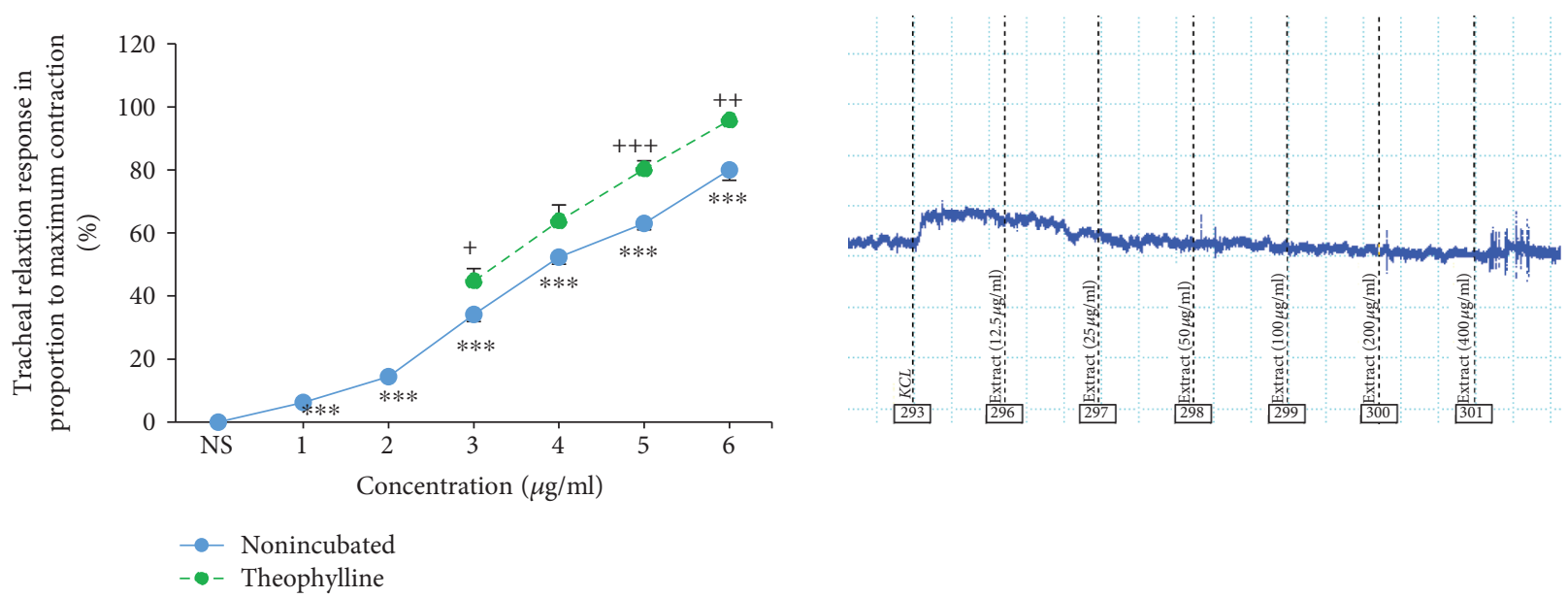

(a)
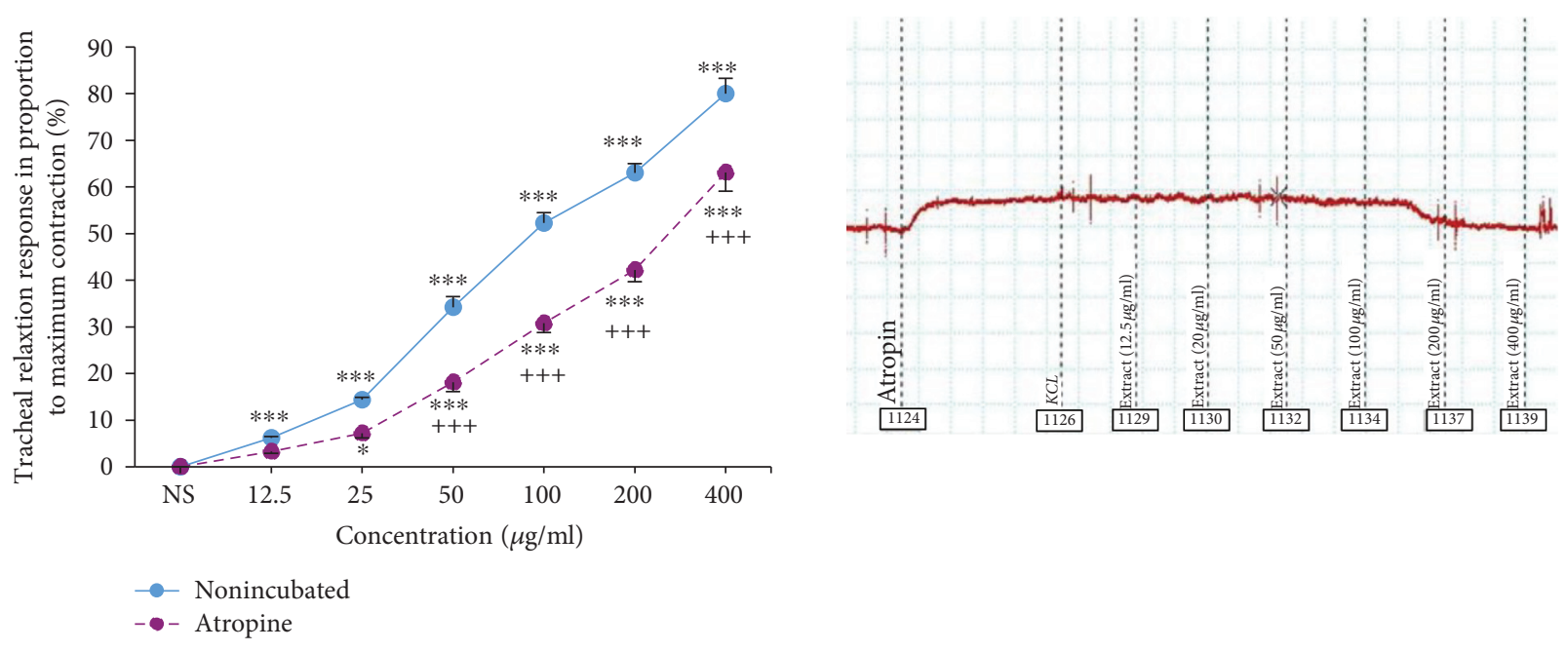

(b)

FIGURE 4: Concentration-response relaxant effect (mean \pm SEM) of (a) theophylline and U. maritima extract in nonincubated TSM contracted by $60 \mathrm{mM} \mathrm{KCl}(n=8) .1,2,3,4,5$, and 6 in $X$-axis show six concentrations of the extract $(12.5,25,50,100,20$, and $400 \mu \mathrm{g} / \mathrm{ml})$ and $3,4,5$, and 6 show theophylline concentrations $(0.2,0.4,0.6$, and $0.8 \mathrm{mM})$ and (b) atropine-incubated TSM $(1 \mu \mathrm{M}, n=6) .{ }^{*} p<0.05$ and ${ }^{* * *} p<0.001$, compared to the effect of saline (NS), $+p<0.05,{ }^{++} p<0.01$, and ${ }^{+++} p<0.001$ in panel (a) indicate comparison between the effect of theophylline and that of the extract. ${ }^{+++} p<0.001$ in panel (b) shows the comparison of the effect of the extract between incubated and nonincubated tissues. ANOVA with the Tukey-Kramer post hoc test was used for statistical comparison.

was no significant difference between the relaxant effects of different concentrations of $U$. maritima extract between the TSM contracted by methacholine or $\mathrm{KCl}$ (Figure 6).

3.4. Correlations between Concentrations of the Extract of U. maritima and Theophylline with Their Relaxant Effects The relaxant effects of theophylline and the extract were significantly correlated with their concentrations in all experimental groups ( $p<0.001$ for all cases) (Table 2).

\section{Discussion}

This study showed concentration-dependent relaxant effect of $U$. maritima extract in nonincubated TSM contracted by methacholine and $\mathrm{KCl}$ comparable to the effect of theophylline. The relaxant effect of $U$. maritima extract in nonincubated TSM contracted by methacholine and $\mathrm{KCl}$ was not significantly different. These results indicate a potent relaxant effect of the plant on TSM, which indicates its bronchodilatory effect in patients with obstructive pulmonary diseases. In fact, the effect of $U$. maritima in the treatment of respiratory diseases was indicated previously [23].

To examine the effect of $U$. maritima on $\beta 2$-receptor [29], muscarinic [32], histamine (H1) [33] receptors, calcium channels [30], and potassium channels [34], ATP-sensitive potassium channels [34] and arachidonic acid metabolism [35] and their contribution in the relaxant effect of the plant were examined on tracheal smooth muscle incubated with propranolol, atropine, chlorpheniramine, diltiazem, glibenclamide, and indomethacin, respectively.

The relaxant effects of the extract in incubated tissues with propranolol, atropine, diltiazem, and glibenclamide 

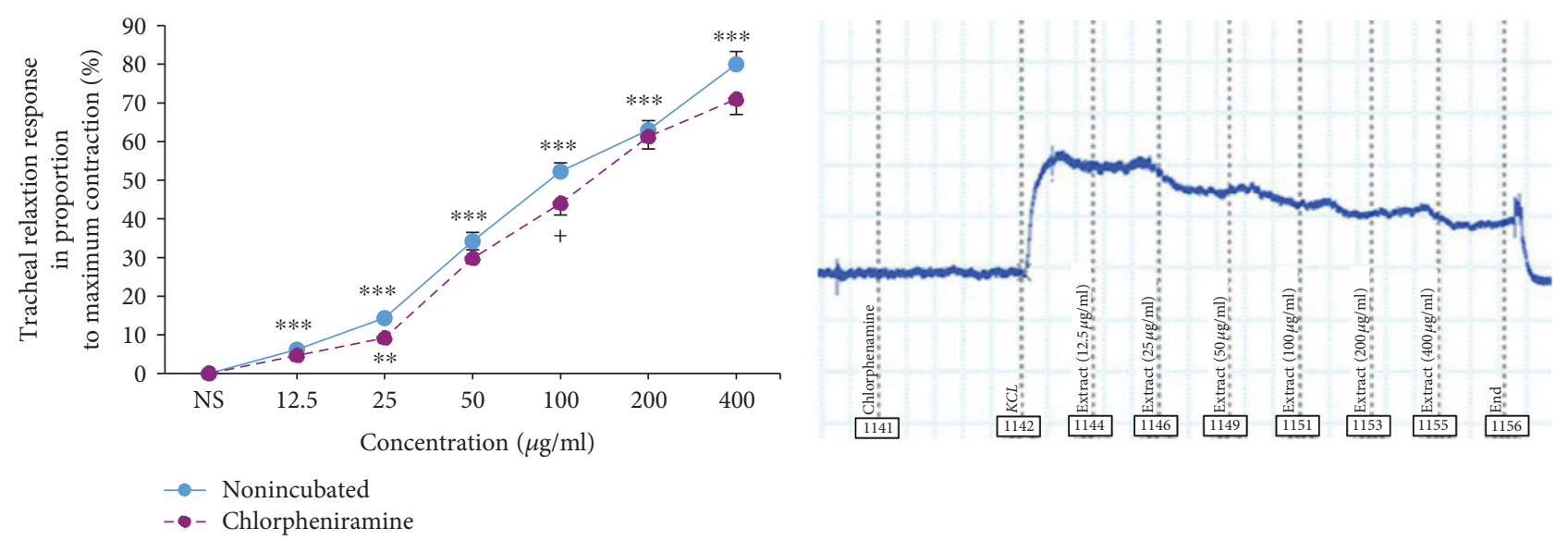

(a)
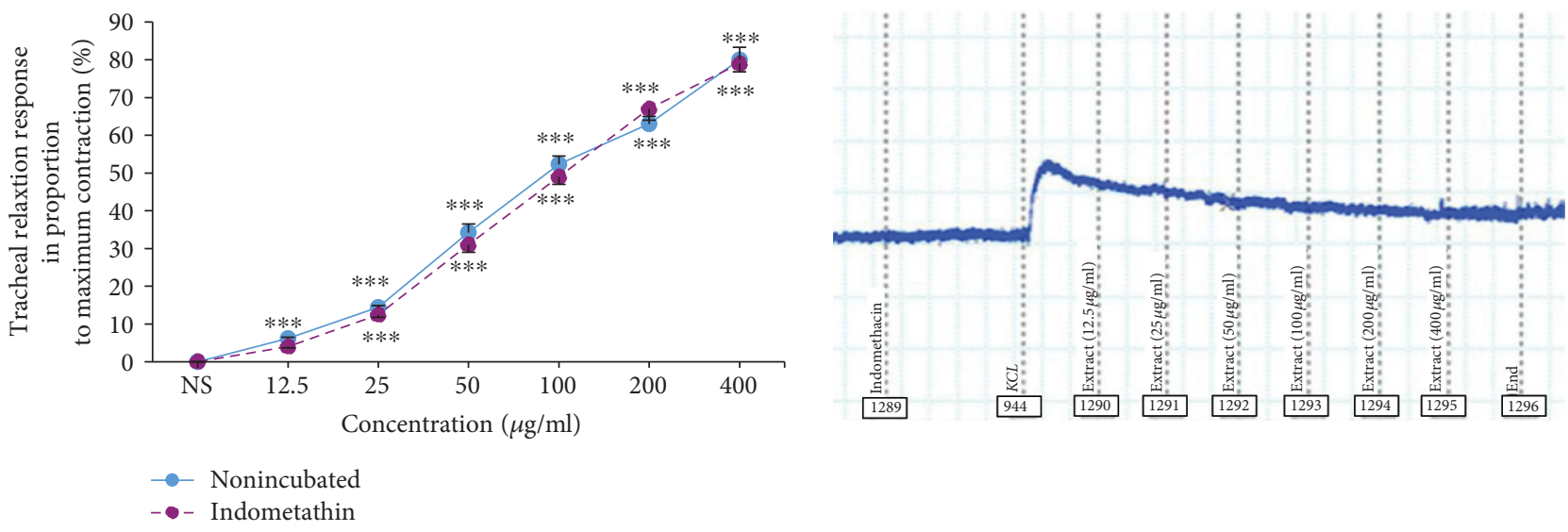

(b)

FIgURE 5: Concentration-response relaxant effects (mean \pm SEM) of $U$. maritima extract on $60 \mathrm{mM} \mathrm{KCl-induced} \mathrm{contraction} \mathrm{of} \mathrm{TSM} \mathrm{in}$ nonincubated and chlorpheniramine-incubated $(1 \mu \mathrm{M})(\mathrm{a})$ and indomethacin-incubated TSM (1 $\mu \mathrm{M})(\mathrm{b})\left(n=8\right.$ for all groups). ${ }^{* *} p<0.01$ and ${ }^{* * *} p<0.001$, compared to the effect of saline (NS), $+p<0.05$ compared to the effect of the extract on nonincubated tissues. ANOVA with the Tukey-Kramer post hoc test was used for statistical comparison.

were significantly lower than those in the nonincubated TSM. These results indicated the stimulatory effect of the plant on $\beta 2$-adrenoceptor, inhibitory effect on muscarinic receptors, calcium channel blocking, and potassium channel opening effects, respectively. The $\mathrm{EC}_{50}$ values of the extract inducing relaxant effect in the incubated tissues with propranolol, atropine, diltiazem, and glibenclamide were also significantly higher compared to those in the nonincubated TSM. The higher $\mathrm{EC}_{50}$ values of the extract inducing relaxant effect in the incubated tissue also support the $\beta 2$-adrenoceptor stimulation, muscarinic receptors inhibition, calcium channel blocking, and potassium channel opening properties of the plant. However, the maximum relaxant response was not obtained in incubated tissues with propranolol, which may indicate nonselective effect of the plant on $\beta 2$ adrenoceptor [28]. The reason for the absence of maximum relaxant effect of the plant in incubated tissues with propranolol could be due to its effect on muscarinic receptors as well as calcium and potassium channels. The effect of another species of $U$. maritima extract on muscarinic receptors was demonstrated previously, which may support the effect of $U$. maritima on muscarinic receptor of TSM [24, 32]. Also, Memarzia and colleagues showed that the most important mechanism involved in relaxant effects of Allium сера (A. серa) extract was $\beta 2$-adrenergic stimulatory and/or calcium channel [24], which may support the results of this study. A former study showed the relaxant activity of the extract of Urginea indica (another plant from Asparagaceae family) with the possible anticholinergic and $\mathrm{Ca}^{2+}$ antagonist mechanisms [27], which also supports the findings of the present study. However, the relaxant effects of U. maritima extract and its $\mathrm{EC}_{50}$ values in incubated tissues with chlorpheniramine and indomethacin were not significantly different from those in the nonincubated tissues. These results indicated the absence of the effect of the plant on histamine (H1) receptor [33] and arachidonic acid metabolism [35] pathways, ATP-sensitive potassium channels [34], and the contribution of these mechanisms to the relaxant effect of $U$. maritima extract on TSM.

This result showed relatively potent relaxant effect of U. maritima extract on TSM and the possible mechanisms of this effect for the first time. The mechanisms responsible for 


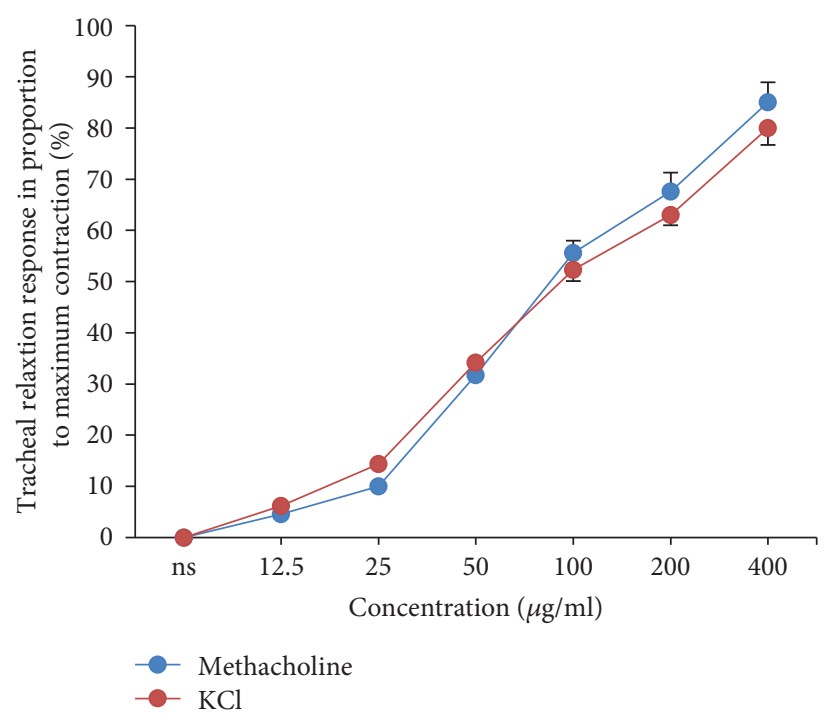

FIGURE 6: Concentration-response relaxant effects of the U. maritima extract in nonincubated tissues, contracted with $10 \mu \mathrm{M}$ methacholine $(n=8)$ and $60 \mathrm{mM} \mathrm{KCl}(n=8)$. There was no significant difference between the relaxant effects of the plant on methacholine or $\mathrm{KCl}$-induced TSM contraction. ANOVA with the Tukey-Kramer post hoc test was used for statistical comparison.

TABLE 2: Correlations between different concentrations and the relaxant effects of $U$. maritima extract and theophylline.

\begin{tabular}{|c|c|c|c|c|}
\hline Contractile agents & Studied agents & Conditions & $R$ & $p$ value \\
\hline \multirow{7}{*}{$\mathrm{KCl}$} & \multirow{4}{*}{ U. maritime } & Nonincubated & 0.967 & $p<0.001$ \\
\hline & & Atropine-incubated & 0.936 & $p<0.001$ \\
\hline & & Indomethacin-incubated & 0.976 & $p<0.001$ \\
\hline & & Chlorpheniramine-incubated & 0.965 & $p<0.001$ \\
\hline & \multirow{3}{*}{ Theophylline } & Nonincubated & 0.899 & $p<0.001$ \\
\hline & & Nonincubated & 0.960 & $p<0.001$ \\
\hline & & Diltiazem-incubated & 0.963 & $p<0.001$ \\
\hline \multirow{3}{*}{ Methacholine } & - & Glibenclamide-incubated & 0.961 & $p<0.001$ \\
\hline & U. maritima & Propranolol-incubated & 0.946 & $p<0.001$ \\
\hline & Theophylline & Nonincubated & 0.966 & $p<0.001$ \\
\hline
\end{tabular}

Data were presented as mean \pm SEM.

the relaxant effect of $U$. maritima extract on TSM are $\beta 2$ adrenergic receptor stimulator, muscarinic receptors inhibition, calcium channel blocking, and potassium channels pathway opening effects or combinations of these mechanisms. The significant relaxant effect of $U$. maritima extract on TSM may indicate a bronchodilator effect for the $U$. maritima extract on obstructive pulmonary diseases.

\section{Conclusions}

In conclusion, this study displayed the potent relaxant effect of $U$. maritima on TSM comparable to the effect of theophylline, indicating its possible bronchodilatory property. Based on the results of this study, the possible mechanisms responsible for the relaxant effect of the plant on TSM are $\beta 2$-adrenoceptor stimulation, muscarinic receptors inhibition, potassium channel opening, and calcium channel blocking properties.

\section{Data Availability}

No data were used to support this study.

\section{Conflicts of Interest}

The authors declare that there are no conflicts of interest with respect to the research, authorship, and/or publication of this article.

\section{Acknowledgments}

This study was financially supported by a grant from Research Council of Mashhad University of Medical Sciences.

\section{References}

[1] L. A. Laitinen, M. Heino, A. Laitinen, T. Kava, and T. Haahtela, "Damage of the airway epithelium and bronchial reactivity in patients with asthma," American Review of Respiratory Disease, vol. 131, no. 4, pp. 599-606, 1985.

[2] G. D’Amato, C. Vitale, A. Molino, A. Stanziola et al., "Asthma-related deaths," Multidisciplinary Respiratory Medicine, vol. 11, p. 37, 2016.

[3] J. R. Murdoch and C. M. Lloyd, "Chronic inflammation and asthma," Mutation Research/Fundamental and Molecular Mechanisms of Mutagenesis, vol. 690, no. 1-2, pp. 24-39, 2010. 
[4] J. Bousquet, E. Mantzouranis, A. A. Cruz et al., "Uniform definition of asthma severity, control, and exacerbations: document presented for the world health organization consultation on severe asthma," Journal of Allergy and Clinical Immunology, vol. 126, no. 5, pp. 926-938, 2010.

[5] S. Chai, K. K. To, and G. Lin, "Circumvention of multi-drug resistance of cancer cells by Chinese herbal medicines," Chinese Medicine, vol. 5, no. 1, pp. 1-9, 2010.

[6] H. Bozcuk, M. Özdogan, O. Aykurt et al., "Urginea maritima (L.) Baker (Liliaceae) extract induces more cytotoxicity than standard chemotherapeutics in the A549 non-small cell lung cancer (NSCLC) cell line," Turkish Journal of Medical Sciences, vol. 41, no. 1, pp. 101-108, 2011.

[7] R. Slimestad, T. Fossen, and I. M. Vågen, "Onions: a source of unique dietary flavonoids," Journal of Agricultural and Food Chemistry, vol. 55, no. 25, pp. 10067-10080, 2007.

[8] C. K. Kokate, A. P. Purohit, and S. B. Gokhale, Text Book of Pharmacognosy, Nirali Prakashan, Pragati Books Private Limited, Pune, India, 2008.

[9] M. Metin and B. Bürün, "Effects of the high doses of Urginea maritima (L.) baker extract on chromosomes," Caryologia, vol. 63, no. 4, pp. 367-375, 2010.

[10] W. Praznik and T. Spies, "Fructo-oligosaccharides from Urginea maritima," Carbohydrate Research, vol. 243, no. 1, pp. 91-97, 1993.

[11] S. Ghosh, A. N. Sarangi, M. Mukherjee, S. Bhowmick, and S. Tripathy, "Reanalysis of lactobacillus paracasei Lbs2 strain and large-scale comparative genomics places many strains into their correct taxonomic position," Microorganisms, vol. 7, no. 11, p. 487, 2019.

[12] O. E. Belhaddad, N. Charef, S. Amamra et al., "Chromatographic fractionation, antioxidant and antibacterial activities of Urginea maritima methanolic extract," Pakistan Journal of Pharmaceutical Sciences, vol. 30, no. 1, pp. 127-134, 2017.

[13] V. Naidoo, D. R. Katerere, G. E. Swan, and J. N. Eloff, "Pretreatment of Urginea sanguinea bulbs used in ethnoveterinary medicine influences chemical composition and biological activity," Pharmaceutical Biology, vol. 42, no. 7, pp. 529-533, 2004.

[14] A. V. Deepak and B. P. Salimath, "Antiangiogenic and proapoptotic activity of a novel glycoprotein from $U$. indica is mediated by NF-KB and caspase activated DNase in ascites tumor model," Biochimie, vol. 88, no. 3-4, pp. 297-307, 2006.

[15] M. Iizuka, T. Warashina, and T. Noro, "Bufadienolides and a new lignan from the bulbs of Urginea maritima," Chemical and Pharmaceutical Bulletin, vol. 49, no. 3, pp. 282-286, 2001.

[16] L. Krenn, M. Jelovina, and B. Kopp, "New bufadienolides from Urginea maritima sensu strictu," Fitoterapia, vol. 71, no. 2, pp. 126-129, 2000.

[17] C. Dias, J. A. B. Graca, and M. L. Goncalves, "Scilla maderensis, TLC screening and positive inotropic effect of bulb extracts," Journal of Ethnopharmacology, vol. 71, no. 3, pp. 487-492, 2000.

[18] H. R. El-Seedi, R. Burman, A. Mansour et al., "The traditional medical uses and cytotoxic activities of sixty-one Egyptian plants: discovery of an active cardiac glycoside from Urginea maritima," Journal of Ethnopharmacology, vol. 145, no. 3, pp. 746-757, 2013.

[19] L. Boulos and M. El-Gohary, Medicinal Plants of North Africa, Reference Publication Incorporated, Washington, DC, USA, 1983.

[20] K. Bielawski, K. Winnicka, and A. Bielawska, "Inhibition of DNA topoisomerases I and II, and growth inhibition of breast cancer MCF-7 cells by ouabain, digoxin and proscillaridin A,"
Biological and Pharmaceutical Bulletin, vol. 29, no. 7, pp. 1493-1497, 2006.

[21] J. Barnes, L. A. Anderson, and J. D. Phillipson, Textbook of Herbal Medicines, Pharmaceutical Press, London, UK, 2007.

[22] D. Bown, The Royal Horticultural Society Encyclopedia of Herbs \& Their Uses, Dorling Kindersley Limited, London, UK, 1995.

[23] J. A. Duke, M. J. Bogenschutz-Godwin, J. Du Celliar, and P. A. K. Duke, Duke PAK Handbook of Medicinal Herbs, CRC Press, Boca Raton, FL, USA, 2002.

[24] A. Memarzia, F. Amin, S. Saadat, M. Jalali, Z. Ghasemi, and M. H. Boskabady, "The contribution of beta-2 adrenergic, muscarinic and histamine $\left(\mathrm{H}_{1}\right)$ receptors, calcium and potassium channels and cyclooxygenase pathway in the relaxant effect of Allium cepa L. on the tracheal smooth muscle," Journal of Ethnopharmacology, vol. 241, Article ID 112012, 2019.

[25] M. H. Boskabady, M. G. Rahbardar, H. Nemati, and M. Esmaeilzadeh, "Inhibitory effect of Crocus sativus (saffron) on histamine $\left(\mathrm{H}_{1}\right)$ receptors of guinea pig tracheal chains," Die Pharmazie-An International Journal of Pharmaceutical Sciences, vol. 65, no. 4, pp. 300-305, 2010.

[26] B. Emami, F. Shakeri, V. Ghorani, and M. H. Boskabady, "Relaxant effect of Curcuma longa on rat tracheal smooth muscle and its possible mechanisms," Pharmaceutical Biology, vol. 55, no. 1, pp. 2248-2258, 2017.

[27] S. Bashir, S. Abbas, A. H. Gilani, and A. Khan, "Studies on bronchodilator and cardiac stimulant activities of Urginea indica," Bangladesh Journal of Pharmacology, vol. 8, no. 3, pp. 249-254, 2013.

[28] O. Arunlakshana and H. Schild, "Some quantitative uses of drug antagonists," British Journal of Pharmacology and Chemotherapy, vol. 14, no. 1, pp. 48-58, 1959.

[29] A. Linden, A. Bergendal, A. Ullman, B.-E. Skoogh, and C.-G. Löfdahl, "Salmeterol, formoterol, and salbutamol in the isolated guinea pig trachea: differences in maximum relaxant effect and potency but not in functional antagonism," Thorax, vol. 48, no. 5, pp. 547-553, 1993.

[30] Y. Miyahara, Y. Kizawa, M. Sano, and H. Murakami, "Effects of organic and inorganic $\mathrm{Ca}\left(2^{+}\right)$-antagonists on acetylcholine-induced contraction in molluscan (Mytilus edulis) smooth muscle," General Pharmacology, vol. 24, no. 6, pp. 1419-1423, 1993.

[31] F. Naghdi, Z. Gholamnezhad, M. H. Boskabady, and M. Bakhshesh, "Muscarinic receptors, nitric oxide formation and cyclooxygenase pathway involved in tracheal smooth muscle relaxant effect of hydro-ethanolic extract of Lavandula angustifolia flowers," Biomedicine \& Pharmacotherapy, vol. 102, pp. 1221-1228, 2018.

[32] B. Loenders, M. Rampart, and A. G. Herman, "Selective M3 muscarinic receptor antagonists inhibit smooth muscle contraction in rabbit trachea without increasing the release of acetylcholine," Journal of Pharmacology and Experimental Therapeutics, vol. 263, no. 2, pp. 773-779, 1992.

[33] V. T. Popa, "Bronchodilating activity of an $\mathrm{H}_{1}$ blocker, chlorpheniramine," Journal of Allergy and Clinical Immunology, vol. 59, no. 1, pp. 54-63, 1977.

[34] M. Miura, M. G. Belvisi, C. D. Stretton, M. H. Yacoub, and P. J. Barnes, "Role of potassium channels in bronchodilator responses in human airways," American Review of Respiratory Disease, vol. 146, no. 1, pp. 132-136, 1992.

[35] M. M. Slattery, A. M. Friel, D. G. Healy, and J. J. Morrison, "Uterine relaxant effects of cyclooxygenase-2 inhibitors in vitro," Obstetrics \& Gynecology, vol. 98, no. 4, pp. 563-569, 2001. 